\title{
RESEARCH
}

Open Access

\section{Mapping current research and identifying hotspots on mesenchymal stem cells in cardiovascular disease}

\author{
Chan Chen ${ }^{1,2^{*}}$, Yang Lou ${ }^{3}$, Xin-Yi Li ${ }^{3}$, Zheng-Tian LV ${ }^{3}$, Lu-Qiu Zhang ${ }^{3}$ and Wei Mao ${ }^{3^{*}}$ (D)
}

\begin{abstract}
Background: Mesenchymal stem cells (MSCs) have important research value and broad application prospects in the cardiovascular disease. This study provides information on the latest progress, evolutionary path, frontier research hotspots, and future research developmental trends in this field.
\end{abstract}

Methods: A knowledge map was generated by CiteSpace and VOSviewer analysis software based on data obtained from the literature on MSCs in the cardiovascular field.

Results: The USA and China ranked at the top in terms of the percentage of articles, accounting for $34.306 \%$ and $28.550 \%$, respectively. The institution with the highest number of research publications in this field was the University of Miami, followed by the Chinese Academy of Medical Sciences and Harvard University. The research institution with the highest ACl value was Harvard University, followed by the Mayo Clinic and the University of Cincinnati.

The top three subjects in terms of the number of published articles were cell biology, cardiovascular system cardiology, and research experimental medicine. The journal with the most publications in this field was Circulation Research, followed by Scientific Reports and Biomaterials. The direction of research on MSCs in the cardiovascular system was divided into four parts: (1) tissue engineering, scaffolds, and extracellular matrix research; (2) cell transplantation, differentiation, proliferation, and signal transduction pathway research; (3) assessment of the efficacy of stem cells from different sources and administration methods in the treatment of acute myocardial infarction, myocardial hypertrophy, and heart failure; and (4) exosomes and extracellular vesicles research. Tissue research is the hotspot and frontier in this field.

Conclusion: MSC research has presented a gradual upward trend in the cardiovascular field. Multidisciplinary intersection is a characteristic of this field. Engineering and materials disciplines are particularly valued and have received attention from researchers. The progress in multidisciplinary research will provide motivation and technical support for the development of this field.

Keywords: Mesenchymal stem cells, Cardiovascular, Knowledge mapping analysis, Visualization

\footnotetext{
*Correspondence: chenchan2009@126.com; maoweilw@163.com

${ }^{1}$ Hangzhou Xiaoshan district Hospital of TCM, Jiangnan Hospital Affiliated to

Zhejiang Chinese Medical University, Hangzhou 311201, Zhejiang, China

${ }^{3}$ The first Affiliated Hospital Zhejiang Chinese Medical University, Hangzhou

311006, Zhejiang, China

Full list of author information is available at the end of the article
}

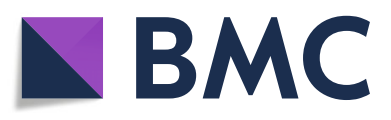

(- The Author(s). 2020 Open Access This article is licensed under a Creative Commons Attribution 4.0 International License, which permits use, sharing, adaptation, distribution and reproduction in any medium or format, as long as you give appropriate credit to the original author(s) and the source, provide a link to the Creative Commons licence, and indicate if changes were made. The images or other third party material in this article are included in the article's Creative Commons licence, unless indicated otherwise in a credit line to the material. If material is not included in the article's Creative Commons licence and your intended use is not permitted by statutory regulation or exceeds the permitted use, you will need to obtain permission directly from the copyright holder. To view a copy of this licence, visit http://creativecommons.org/licenses/by/4.0/ The Creative Commons Public Domain Dedication waiver (http://creativecommons.org/publicdomain/zero/1.0/) applies to the data made available in this article, unless otherwise stated in a credit line to the data. 


\section{Introduction}

Mesenchymal stem cells (MSCs) are widely perceived as a class of adult pluripotent stem cells with multiple differentiation potentials, which derived from mesoderm and neuroectoderm and do not express hematopoieticrelated markers [1]. The important biological characteristics of MSCs include its low level of expression of human leukocyte antigen class I molecules and CD40, CD40 ligand, CD80, or CD86, which is required to induce effector T cells [2]. MSCs have low immunogenicity and immunoregulatory effects, which can affect every cell of the immune system through cell-cell interactions and paracrine effects [3]. Based on these special biological characteristics, MSCs have important research value and broad application prospects.

Recent studies have shown that the use of MSCs has made great progress in cardiovascular basic and clinical research. MSCs induce the differentiation of cardiomyocytes and vascular endothelial cells. Bonnet found that BMSCs induced in vitro can express platelet-derived growth factor receptor (PDGFR), smooth muscle myosin heavy chain 11 (SMMHC11), and myoglobulin light chain 2 (MLC2), which is similar to that observed in aortic smooth muscle cells, and BMSCs have similar electrophysiological activity and contraction ability [4]. MSCs inhibit myocardial fibrosis; for example, MSC exosomes reduce fibrosis of the heart by inhibiting the proliferation of fibroblasts, promoting the synthesis of metalloproteinases, and stimulating angiogenesis in the infarct area [5]. MSCs also promote angiogenesis. Rahbarghazi transplanted MSCs into infarcted myocardium in rabbits and found that the surrounding area of infarcted myocardium mainly differentiated into cardiomyocytes, endothelial cells, and smooth muscle cells, and the microvessel density significantly increased [6]. MSCs can effectively treat myocardial infarction, dilated cardiomyopathy, heart failure, and other conditions. For example, Lee et al. proved that intravenous injection of bone marrow MSCs was safe, mild, and effective and had a long-lasting effect [7]. Chin et al. confirmed that autologous bone marrow-derived MSCs were safe and effective in treating DCM [8]. Bartunek et al. found that MSC therapy did not produce myocardial toxicity, which significantly increased the left ventricular ejection fraction, reduced the end-systolic volume, and increased the 6-min walking distance of HF patients [9].

Bibliometrics uses the literature system and bibliometric characteristics as the research object and conducts quantitative and qualitative analysis of the literature [10]. It allows the quantitative measurement of the profile distribution as well as the relationships and clustering of studies [11]. In addition to describing and predicting the development of a particular research area, this type of analysis can also compare the contributions of different countries, institutions, journals, and scholars [12]. This type of analysis technology is playing an increasingly important role in developing guidelines and evaluating research trends [13]. Many scholars have used this method of literature analysis in various fields of medicine, such as spinal surgery research [14], health information research [15], biological signaling molecule research [16], neurogenetics research [17], and endocrine disease research [18].

This research is based on data regarding the literature on MSCs in the cardiovascular field, which uses CiteSpace and VOSviewer to form a corresponding knowledge map and recognize the knowledge base. The study provides information on the latest progress, evolutionary path, frontier research hotspots, and future research developmental trends in this field.

\section{Methods}

\section{Data collection}

SCI-E and SSCI of the core database of the document information index database Web of Science were selected as the target databases for source document retrieval. The search formula was set to TS $=$ ("cardiovascular" OR "heart" OR "circulation") AND TS = (mesenchymal stem cells), and the dates of the search were from January 1, 2010, to March 31, 2020, which resulted in a total of 3455 records. There were 8 types of documents among the 3455 records. As shown in Table 1, there were 2380 articles, which accounted for $72.187 \%$ of the total number of records, making articles the most common type of literature. Reviews ranked second, as there were 755 reviews, accounting for $22.900 \%$ of the total. The other 8 document types were meeting abstracts (98), editorial materials (55), book chapters (35), proceedings papers (32), early access (20), letters (5), corrections (3), and news items (1).

\section{Data analysis}

VOSviewer and CiteSpace were used to analyze the 3384 exported articles. VOSviewer constructs a map based on the cooccurrence matrix. The construction of the map is a three-step process. In the first step, the similarity matrix is calculated based on the cooccurrence matrix. In the second step, the VOS mapping technique is applied to the similarity matrix to construct a map. Finally, in the third step, the map is translated, rotated, and reflected [19]. The term cooccurrence graph in VOSviewer only includes terms that appear in the title and are abstracted at least 50 times under the binary count [19]. The purpose of the algorithm is to ensure that terms that occur more frequently have larger bubble images and that terms with high similarity are close to each other [20]. CiteSpace is a web-based Java application that focuses on detecting and analyzing the evolution of research frontiers and the relationship between research 
Table 1 Document types of the publications

\begin{tabular}{|c|c|c|c|c|c|c|}
\hline No. & Type of document & TP & SOTC & CA & Proportion/\% & $h$-index \\
\hline 1 & Article & 2380 & 54,115 & 32,037 & 72.187 & 89 \\
\hline 2 & Review & 755 & 25,090 & 20,693 & 22.900 & 77 \\
\hline 3 & Meeting Abstract & 98 & 16 & 12 & 2.972 & 1 \\
\hline 4 & Editorial Material & 55 & 411 & 403 & 1.668 & 9 \\
\hline 5 & Book Chapter & 35 & 946 & 943 & 1.062 & 12 \\
\hline 6 & Proceedings Paper & 32 & 891 & 871 & 0.971 & 15 \\
\hline 7 & Early Access & 20 & 5 & 5 & 0.607 & 1 \\
\hline 8 & Letter & 5 & 8 & 8 & 0.152 & 2 \\
\hline 9 & Correction & 3 & 7 & 7 & 0.091 & 2 \\
\hline 10 & News Item & 1 & 0 & 0 & 0.030 & 0 \\
\hline
\end{tabular}

TP total publications, SOTC sum of times cited, CA citing articles

frontiers and their knowledge base. CiteSpace also examines the internal connections between different research frontiers [21]. It is used to capture keywords associated with strong citation bursts, which can be used as predictors of research frontiers.

\section{Results}

\section{Temporal distribution map of the literature}

From 2010 to 2018, the number of research publications on MSCs in the cardiovascular field generally showed an upward trend (Fig. 1). From 2010 to 2013, the number of articles published in this field rose steadily, with a slight decline in 2014, an increase in 2015, and a decline in 2016. The number of articles increased each year from 2017 to 2018. In 2018, the number of articles reached its peak and then declined in 2019. As shown in Fig. 1, documents published between 2010 and 2015 were cited more frequently, and the most cited articles were published in 2011.

\section{Country/region distribution}

As shown in Table 2, the number of articles published by the USA and China placed them at the top of the ranking, as each accounted for $34.306 \%$ and $28.550 \%$ of the total, respectively. The total number of studies conducted by both countries comprised more than half of the total, indicating that the two countries had high research interest in this field. The top three countries in terms of ACI values were the Netherlands (40.2288), Spain (34.2771), and the USA (32.5757), suggesting that these three countries had started to conduct research in this field earlier than other countries and that their research results were more mature.

As shown in Fig. 2, countries with close cooperation can be mainly divided into three types. The green part: the USA and China showed the greatest cooperation with South Korea, Japan, Canada, and Australia. The brown part: Germany and Italy worked more closely with England, Netherlands, France, Switzerland, and Spain. The blue part: Singapore contacted with New

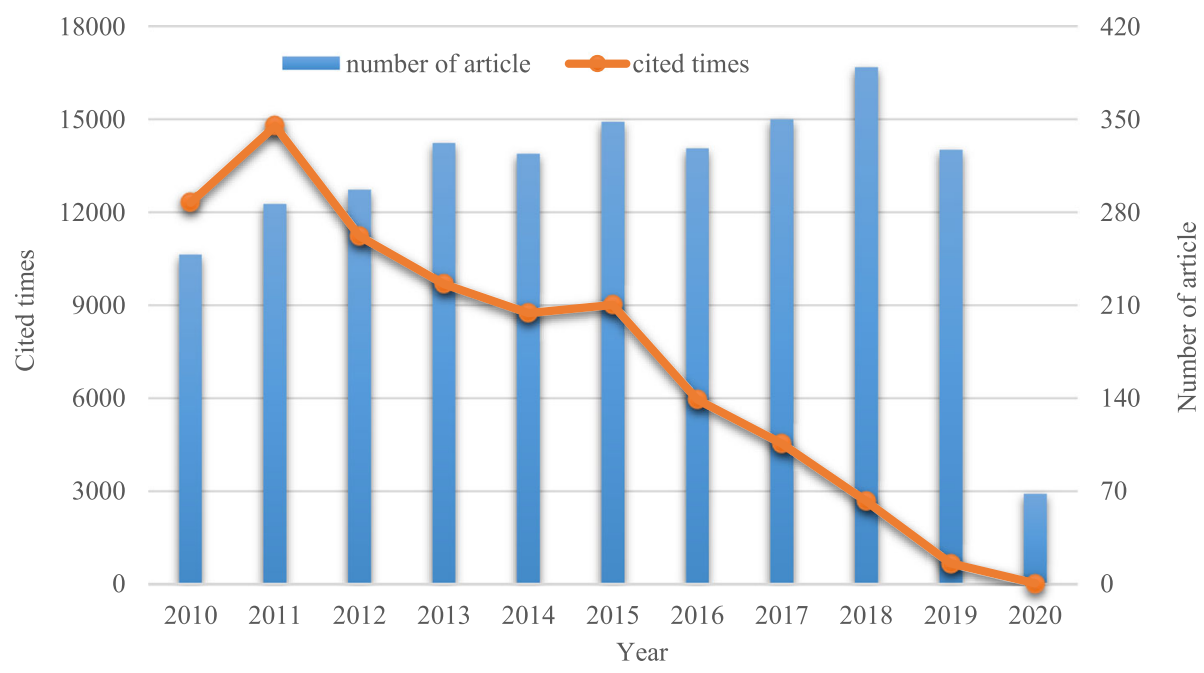

Fig. 1 Trends in the growth of publications and the number of cited articles worldwide from 2010 to 2020 
Table 2 Top 10 productive countries in regard to the research on mesenchymal stem cells in cardiovascular disease

\begin{tabular}{|c|c|c|c|c|c|c|c|}
\hline Rank & Country & Region & Quantity & Percentage & $\mathrm{ACl}$ & $H$-index & $\begin{array}{l}\text { Total link } \\
\text { strength }\end{array}$ \\
\hline 1 & USA & North America & 1129 & 34.306 & 32.5757 & 89 & 541 \\
\hline 2 & China & East Asia & 919 & 28.550 & 16.7737 & 53 & 258 \\
\hline 3 & Italy & South Europe & 188 & 5.840 & 26.766 & 38 & 157 \\
\hline 4 & Germany & Central Europe & 184 & 5.716 & 32.4293 & 43 & 168 \\
\hline 5 & South Korea & East Asia & 144 & 4.473 & 21.4861 & 31 & 68 \\
\hline 6 & England & Western Europe & 126 & 3.914 & 27.2619 & 32 & 143 \\
\hline 7 & Netherlands & Western Europe & 118 & 3.555 & 40.2288 & 40 & 100 \\
\hline 8 & Canada & North America & 116 & 3.604 & 28.2586 & 30 & 78 \\
\hline 9 & Japan & East Asia & 115 & 3.573 & 25.5304 & 30 & 66 \\
\hline 10 & Spain & Southern Europe & 83 & 2.578 & 34.2771 & 27 & 59 \\
\hline
\end{tabular}

$\mathrm{ACl}$ average citations per item

Zealand and Portugal closely, and Malaysia worked more frequently with India.

\section{Distribution of authors and research institutions}

As shown in Table 3, Hare JM from the University of Miami in the USA has the highest number of published articles, followed by Wang Y from Shanghai Jiao Tong University in China and Zhang $\mathrm{Yu}$ from the Second Military Medical University in China. Seven of the top ten writers are from China, and three are from the USA.
As shown in Fig. 3, different colors represent clusters of close cooperation. For examples, Ashraf and Muhammad worked closely with Wang Yigang and Huang Wei. Li Renke worked closely with Steinhoff, Gustav, David Robert, Guan Jianjun, Khan Mahmood, and so on.

As shown in Table 4, the institution with the highest number of research publications in this field is the University of Miami with a quantity of 73, followed by the Chinese Academy of Medical Sciences with a quantity of 55 and Harvard University with a quantity of 52 . The research institution with the highest ACI value in

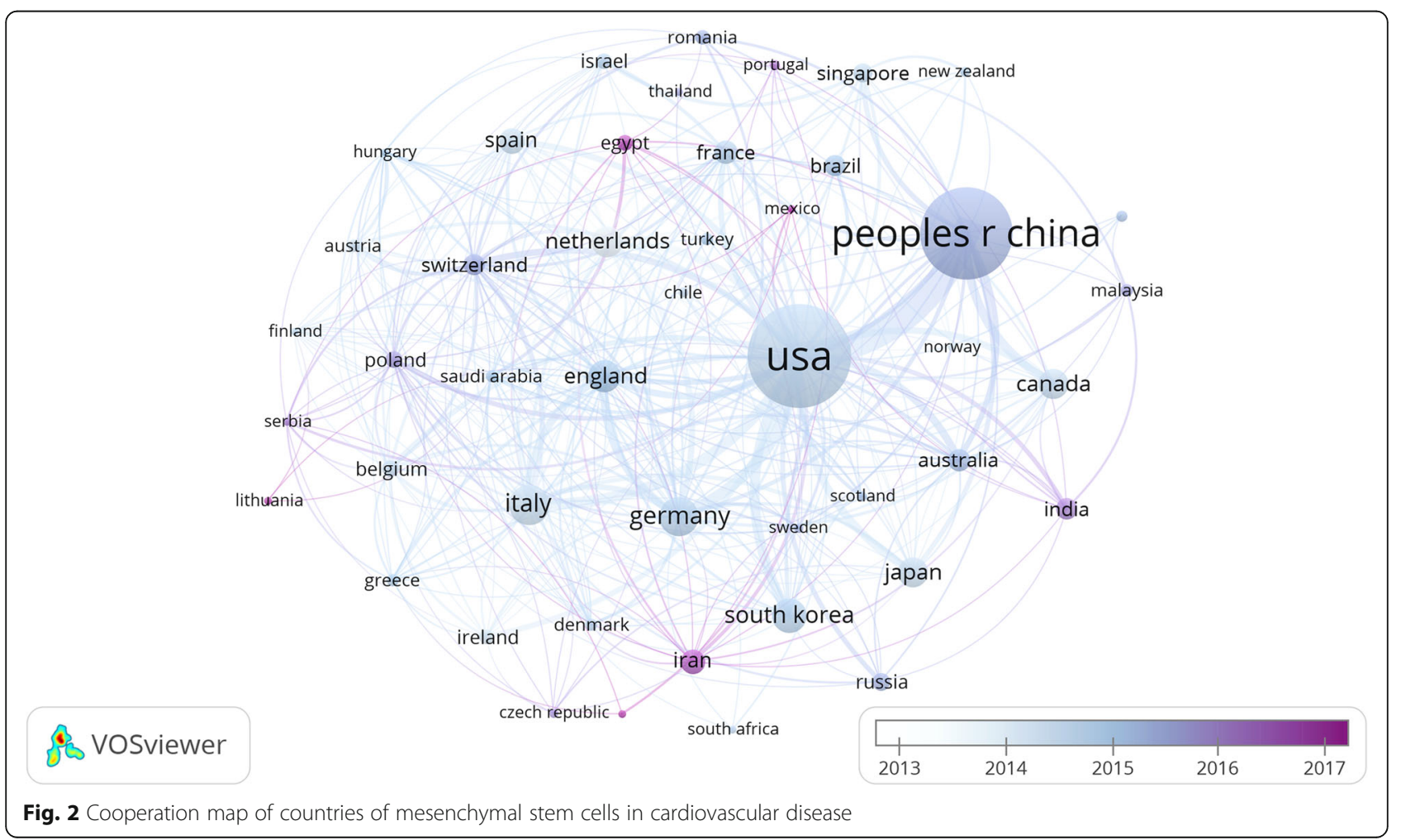


Table 3 Top 15 authors in the studies of mesenchymal stem cells in cardiovascular disease

\begin{tabular}{|c|c|c|c|c|c|c|}
\hline Rank & Author & Country & Institute & TP & $P$ & $h$ \\
\hline 1 & Hare JM & USA & Univ Miami & 64 & $1.941 \%$ & 28 \\
\hline 2 & Wang $Y$ & China & Shanghai Jiao Tong Univ & 58 & $1.759 \%$ & 21 \\
\hline 3 & Zhang, Yu & China & Second Mil Med Univ & 42 & $1.274 \%$ & 21 \\
\hline 4 & Zhang, Lei & China & Southeast Univ & 39 & $1.183 \%$ & 16 \\
\hline 5 & Ashraf, Muhammad & USA & Augusta Univ & 32 & $0.971 \%$ & 18 \\
\hline 6 & Li, Yan & China & Fourth Mil Med Univ & 27 & $0.819 \%$ & 11 \\
\hline 7 & $\mathrm{Li}, \mathrm{Xin}$ & China & Guangdong Acad Med Sci & 26 & $0.789 \%$ & 11 \\
\hline 8 & Liu, Yue & China & China Acad Chinese Med Sci & 25 & $0.758 \%$ & 8 \\
\hline 9 & Cao, Feng & China & Fourth Mil Med Univ & 24 & $0.728 \%$ & 16 \\
\hline 10 & Heldman, Alan W. & USA & Univ Miami & 24 & $0.728 \%$ & 15 \\
\hline
\end{tabular}

TP total publications, $h \mathrm{H}$-index

this field was Harvard University, which had an ACI value of 92.2692, followed by Mayo Clinic with an ACI value of 36.5227 and University of Cincinnati with an ACI value of 34.5455 .

As shown in Fig. 4, different colors mean clusters of intimate relationship. The University of Miami cooperated closely with Harvard University, Pittsburgh University, and Zhejiang University. Sun Yat-sen University cooperated closely with Fudan University, and so on.

\section{Distribution of disciplines in the literature}

As shown in Table 5, the top three disciplines in terms of the number of published articles were cell biology (30.664\%), cardiovascular system cardiology (20.534\%), and research experimental medicine (20.140\%). Additional disciplines represented in the literature were engineering
(9.827\%), materials science $(9.160 \%)$, biochemistry and molecular biology (8.280\%), biotechnology and applied microbiology (7.158\%), pharmacology and pharmacy (6.946\%), transplantation (4.974\%), chemistry (3.063\%), and other disciplines, indicating that the research performed in this field was broad and that the research methods were diverse.

As shown in Table 6, the journal with the highest number of articles in this field was Circulation Research, followed by Scientific Reports (42), Biomaterials (40), Molecular Medicine Reports (40), Stem Cells (39), and Tissue Engineering Part A (39). The magazine with the highest ACI value was Biomaterials (17.68), followed by Stem Cells Translational Medicine (17.45), Journal of Cellular and Molecular Medicine (16.48), Circulation Research (15.30), Tissue Engineering Part A (14.8182),

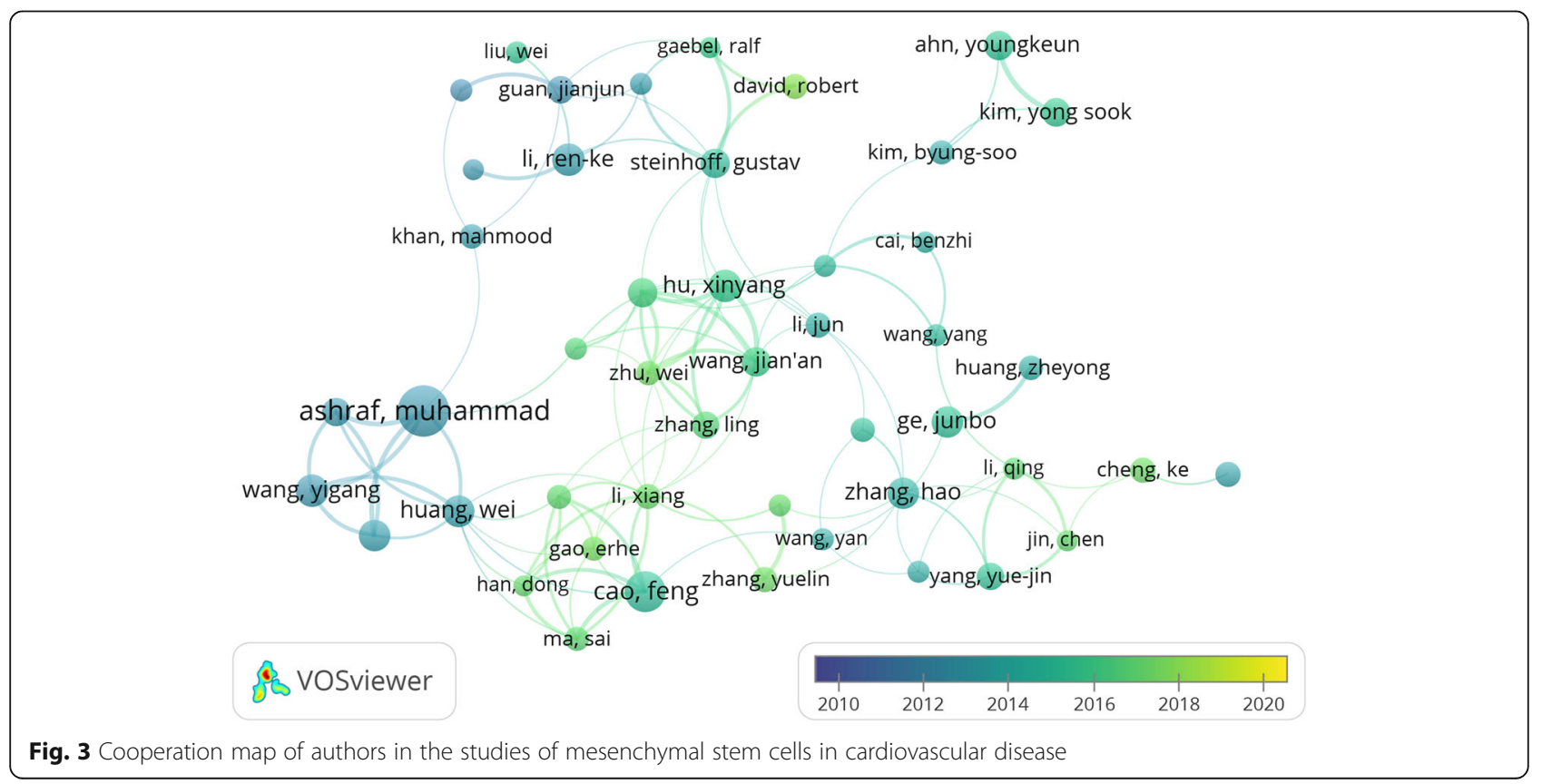


Table 4 Top 10 institutions in the studies of mesenchymal stem cells in cardiovascular disease

\begin{tabular}{|c|c|c|c|c|c|c|}
\hline Rank & Institution & Country & Quantity & Total link strength & STC & $\mathrm{ACl}$ \\
\hline 1 & Univ Miami & USA & 73 & 23 & 3339 & 45.7397 \\
\hline 2 & Chinese Acad Med Sci & China & 55 & 57 & 1319 & 23.9818 \\
\hline 3 & Harvard Univ & USA & 52 & 24 & 4798 & 92.2692 \\
\hline 4 & Sun Yat-sen Univ & China & 51 & 5 & 626 & 12.2745 \\
\hline 5 & Fourth Mil Med Univ & China & 48 & 25 & 883 & 18.3958 \\
\hline 6 & Peking Union Med Coll & China & 47 & 55 & 1173 & 24.9574 \\
\hline 7 & Mayo Clin & USA & 44 & 9 & 1607 & 36.5227 \\
\hline 8 & Univ Cincinnati & USA & 44 & 9 & 1520 & 34.5455 \\
\hline 9 & Univ Toronto & Canada & 44 & 14 & 1410 & 32.0455 \\
\hline 10 & Fudan Univ & China & 42 & 13 & 762 & 18.1429 \\
\hline
\end{tabular}

STC sum of the times cited, $\mathrm{ACl}$ average citations per item

Cell Transplantation (14.78), and Scientific Reports (13.9167).

\section{Highly cited literature analysis}

As shown in Table 7, the article "Pericytes: Developmental, Physiological, and Pathological Perspectives, Problems, and Promises" was cited the most often. Armulik discussed the important roles of pericytes in the processes of organismal development and vascular homeostasis and their relationship with MSCs [22].

The second most cited article was "Comparison of Allogeneic vs Autologous Bone Marrow-Derived
Mesenchymal Stem Cells Delivered by Transendocardial Injection in Patients with Ischemic Cardiomyopathy: The POSEIDON Randomized Trial". In this article, Hare et al. confirmed that intracardiac injection of allogeneic and autologous MSCs could treat ischemic cardiomyopathy effectively and relatively safely [23].

The third most cited article was "Whole-Organ Tissue Engineering: Decellularization and Recellularization of Three-Dimensional Matrix". In this article, Badylak explained that the combination of three-dimensional bioscaffold materials and cell transplantation was a promising tissue engineering strategy and a method for

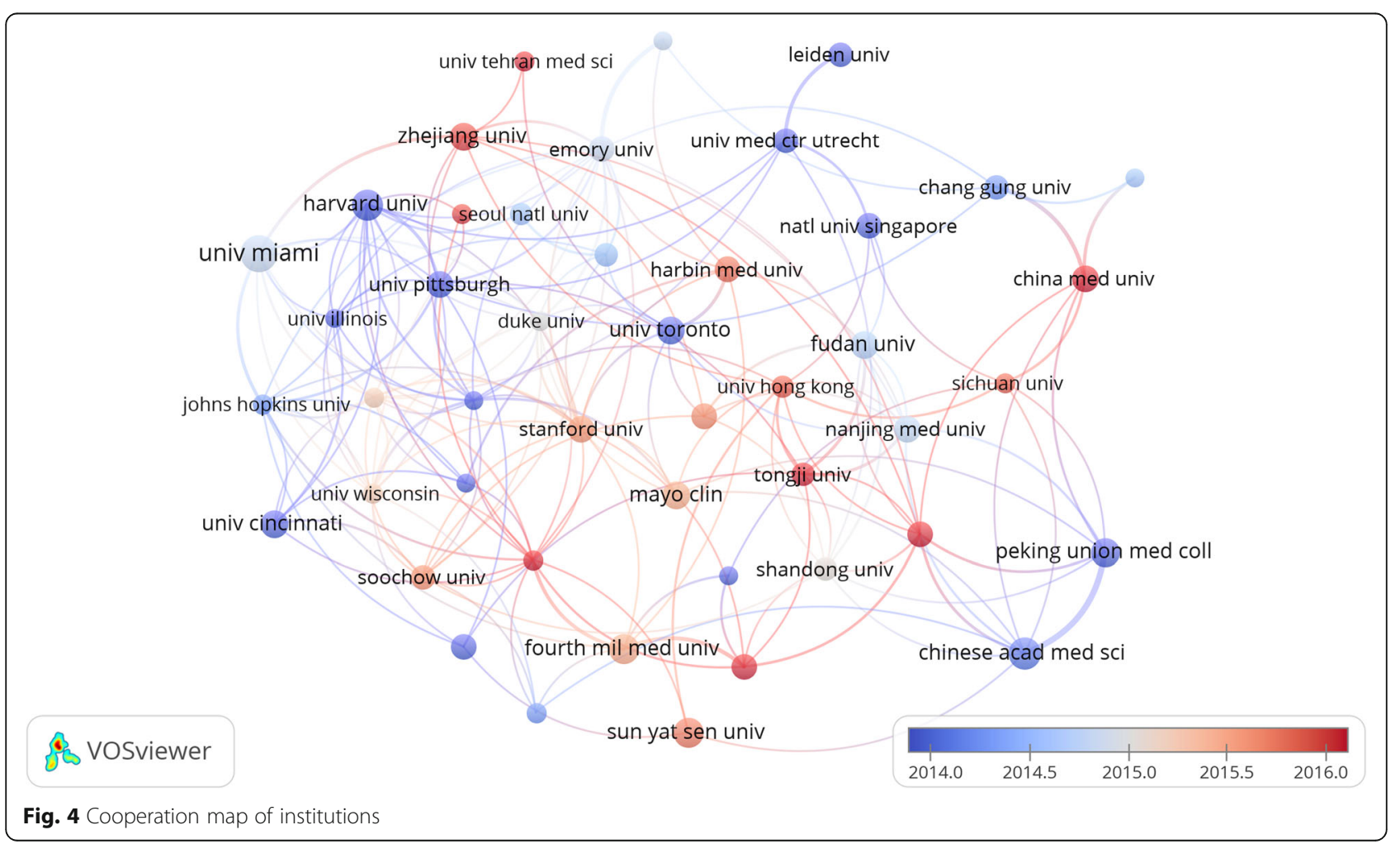


Table 5 The top 20 subject categories in the studies of mesenchymal stem cells in cardiovascular disease

\begin{tabular}{|c|c|c|c|}
\hline Rank & Quantity & WOS categories & Percentage \\
\hline 1 & 1011 & Cell biology & 30.664 \\
\hline 2 & 677 & Cardiovascular system cardiology & 20.534 \\
\hline 3 & 664 & Research experimental medicine & 20.140 \\
\hline 4 & 324 & Engineering & 9.827 \\
\hline 5 & 302 & Materials science & 9.160 \\
\hline 6 & 273 & Biochemistry and molecular biology & 8.280 \\
\hline 7 & 236 & Biotechnology and applied microbiology & 7.158 \\
\hline 8 & 232 & Science technology_-other topics & 7.073 \\
\hline 9 & 229 & Pharmacology and pharmacy & 6.946 \\
\hline 10 & 222 & Hematology & 6.733 \\
\hline 11 & 164 & Transplantation & 4.974 \\
\hline 12 & 159 & Oncology & 4.823 \\
\hline 13 & 129 & Physiology & 3.913 \\
\hline 14 & 123 & Surgery & 3.731 \\
\hline 15 & 101 & Chemistry & 3.063 \\
\hline 16 & 96 & General internal medicine & 2.912 \\
\hline 17 & 80 & Endocrinology and metabolism & 2.426 \\
\hline 18 & 62 & Respiratory system & 1.880 \\
\hline 19 & 57 & Biophysics & 1.729 \\
\hline 20 & 57 & Immunology & 1.729 \\
\hline
\end{tabular}

Table 6 Top 15 journals in the studies of mesenchymal stem cells in cardiovascular disease

\begin{tabular}{llll}
\hline Rank & Journal title & Quantity & $\mathbf{A C l}$ \\
\hline 1 & Circulation Research & 49 & 15.30 \\
2 & Scientific Reports & 42 & 13.9167 \\
3 & Biomaterials & 40 & 17.68 \\
4 & Molecular Medicine Reports & 40 & 12.4091 \\
5 & Stem Cells & 39 & 8.95 \\
6 & Tissue Engineering Part A & 39 & 14.8182 \\
7 & Stem Cells And Development & 28 & 13.66 \\
8 & Cell Transplantation & 27 & 14.78 \\
9 & Circulation & 25 & 11.48 \\
10 & Journal of Cellular and Molecular Medicine & 24 & 16.48 \\
11 & International Journal of Cardiology & 22 & 2.25 \\
12 & PLOS One & 22 & 7.02 \\
13 & Stem Cell Research \& Therapy & 18 & 6.16 \\
14 & Stem Cells Translational Medicine & 17 & 17.45 \\
15 & Stem Cells International & 11 & 5.15 \\
\hline
\end{tabular}

$\mathrm{ACl}$ average citations per item the regeneration of functional organs for medical replacement [24]. The above articles could be regarded as constituting an important theoretical basis and providing clinical evidence for research in this field.

According to the types of the articles, 8 of the most highly cited articles were reviews, and 7 were monographs. Based on the publication dates of the most highly cited articles, the most highly cited articles were published from 2011 to 2013, followed by 2015 to 2016 . These periods can be regarded as representing the two stages of the development of this field. Based on the numbers of cooperating institutions and countries, there were 10 articles involving more than three institutions and 6 articles involving groups in at least two countries.

\section{Research hotspots and frontier analysis Research hotspot analysis}

Keywords reflect the core content of the article and can be used to identify the evolving research frontiers related to the knowledge field [25]. As shown in Table 8, in addition to mesenchymal stem cells and heart, the keywords with a high frequency of occurrence were heart transplantation (582), differentiation (535), myocardial infarction (482), in vitro (473), therapy (472), and progenitor cells (458). 
Table 7 Top 15 co-cited articles, cited authors, and cited references

\begin{tabular}{|c|c|c|c|c|c|c|c|c|}
\hline Rank & Title & Journal & Type & Authors & $\mathrm{Y}$ & $\mathrm{C}$ & IN & $\mathrm{CN}$ \\
\hline 1 & $\begin{array}{l}\text { Pericytes: Developmental, Physiological, and } \\
\text { Pathological Perspectives, Problems, and } \\
\text { Promises }\end{array}$ & Developmental Cell & Review & Armulik, Annika.et al. & 2011 & 1086 & 2 & 2 \\
\hline 2 & $\begin{array}{l}\text { Comparison of Allogeneic vs Autologous } \\
\text { Bone Marrow-Derived Mesenchymal Stem } \\
\text { Cells Delivered by Trans }\end{array}$ & $\begin{array}{l}\text { Journal of the American } \\
\text { Medical Association }\end{array}$ & Article & Hare, Joshua M.et al. & 2012 & 639 & 8 & 1 \\
\hline 3 & $\begin{array}{l}\text { Whole-Organ Tissue Engineering: } \\
\text { Decellularization and Recellularization of } \\
\text { Three-Dimensional Matrix }\end{array}$ & $\begin{array}{l}\text { Annual Review of } \\
\text { Biomedical Engineering }\end{array}$ & Review & Badylak, Stephen F.et al. & 2011 & 516 & 7 & 1 \\
\hline 4 & $\begin{array}{l}\text { Bone Marrow Mesenchymal Stem Cells } \\
\text { Stimulate Cardiac Stem Cell Proliferation } \\
\text { and Differentiation }\end{array}$ & Circulation Research & Article & Hatzistergos, Konstantinos E. et al. & 2010 & 469 & 5 & 2 \\
\hline 5 & $\begin{array}{l}\text { Molecular mechanisms of cancer } \\
\text { development in obesity }\end{array}$ & Nature Reviews Cancer & Review & Khandekar, Melin J. et al. & 2011 & 467 & 4 & 1 \\
\hline 6 & $\begin{array}{l}\text { Harnessing the Mesenchymal Stem Cell } \\
\text { Secretome for the Treatment of } \\
\text { Cardiovascular Disease }\end{array}$ & Cell Stem Cell & Review & Ranganath, Sudhir H. et al. & 2012 & 449 & 6 & 2 \\
\hline 7 & $\begin{array}{l}\text { Conversion of vascular endothelial cells into } \\
\text { multipotent stem-like cells }\end{array}$ & Nature Medicine & Article & Medici, Damian et al. & 2010 & 444 & 8 & 1 \\
\hline 8 & $\begin{array}{l}\text { Mesenchymal stem cell-derived exosomes } \\
\text { increase ATP levels, decrease oxidative } \\
\text { stress and activate P }\end{array}$ & Stem Cell Research & Article & Arslan, Fatih Et al. & 2013 & 436 & 8 & 2 \\
\hline 9 & $\begin{array}{l}\text { Clinical Trials With Mesenchymal Stem Cells: } \\
\text { An Update }\end{array}$ & Cell Transplantation & Review & Squillaro, Tiziana et al. & 2016 & 411 & 4 & 3 \\
\hline 10 & $\begin{array}{l}\text { Aggregation of human mesenchymal } \\
\text { stromal cells (MSCs) into 3D spheroids } \\
\text { enhances their antiinflammat }\end{array}$ & $\begin{array}{l}\text { Proceedings of the } \\
\text { National Academy of } \\
\text { Sciences of the United } \\
\text { States of America }\end{array}$ & Article & Bartosh, Thomas J. et al. & 2010 & 411 & 1 & 1 \\
\hline 11 & $\begin{array}{l}\text { Perivascular Gli1(+) Progenitors Are Key } \\
\text { Contributors to Injury-Induced Organ } \\
\text { Fibrosis }\end{array}$ & Cell Stem Cell & Article & Kramann, Rafael. et al. & 2015 & 337 & 6 & 2 \\
\hline 12 & $\begin{array}{l}\text { Cell Therapy for Heart Failure: A } \\
\text { Comprehensive Overview of Experimental } \\
\text { and Clinical Studies, Curren }\end{array}$ & Circulation Research & Review & Sanganalmath, Santosh K. et al. & 2013 & 332 & 2 & 1 \\
\hline 13 & $\begin{array}{l}\text { Immunosuppressive Properties of } \\
\text { Mesenchymal Stem Cells: Advances and } \\
\text { Applications }\end{array}$ & $\begin{array}{l}\text { Current Molecular } \\
\text { Medicine }\end{array}$ & Review & De Miguel, M. P. et al. & 2012 & 327 & 4 & 1 \\
\hline 14 & $\begin{array}{l}\text { The war against heart failure: the } \\
\text { Lancet lecture }\end{array}$ & Lancet & Review & Braunwald, Eugene. & 2015 & 301 & 2 & 1 \\
\hline 15 & $\begin{array}{l}\text { Bone Marrow-Derived Cell Therapy } \\
\text { Stimulates Endogenous Cardiomyocyte } \\
\text { Progenitors and Promotes Cardia }\end{array}$ & Cell Stem Cell & Article & Loffredo, Francesco S. et al. & 2011 & 292 & 2 & 1 \\
\hline
\end{tabular}

$Y$ year, $C$ citations, IN institute number, $C N$ country number

As shown in Fig. 5, in the keyword cooccurrence network map, the thicker the connection between the nodes is, the more frequently the two keywords appear together. The keywords formed 4 clusters, which represented the four major research directions in the field.

The blue cluster was predominated by tissue engineering, scaffolds, and extracellular matrix. Tissue engineering researched the potential efficacy of HTMSCs [26], ADMS Cs [27], and HUCMSCs [28] in repairing myocardial tissue. It studied elastic polyurethane nanofiber [29], copolymerization material [30], nano cellulose patch [31], and 3D biomaterial [32] to promote integration of MSCs and myocardial tissue. Scaffolds explored nanofiber scaffold [33, 34], collagen scaffold [35], alginate scaffold [36], biomatrix scaffolds [36, 37], and porous polysaccharidebased scaffold [38]. Extracellular matrix discussed decellularized bovine myocardial extracellular matrix-based films(dMEbF) [39], synthetic extracellular matrix mimic hydrogel [40], cardiac fibroblast-derived 3D extracellular matrix [41], and porcine small intestinal submucosal extracellular matrix [42] enhanced functions of MSC.

The yellow cluster was mainly composed of transplantation, differentiation, proliferation, oxidative stress, inflammation, and apoptosis. The first three parts 
Table 8 The top 20 keywords in the studies of mesenchymal stem cells in cardiovascular disease

\begin{tabular}{|c|c|c|c|c|c|c|c|}
\hline Rank & Keywords & Occurrences & $\begin{array}{l}\text { Total link } \\
\text { strength }\end{array}$ & Rank & Keywords & Occurrences & $\begin{array}{l}\text { Total link } \\
\text { strength }\end{array}$ \\
\hline 1 & Mesenchymal stem cells & 1529 & 6487 & 11 & Myocardial infarction & 456 & 3032 \\
\hline 2 & Heart & 594 & 3166 & 12 & Bone marrow & 449 & 2468 \\
\hline 3 & Transplantation & 582 & 3386 & 13 & Expression & 362 & 1782 \\
\hline 4 & Mesenchymal stem cells & 561 & 3066 & 14 & Acute myocardial infarction & 331 & 1985 \\
\hline 5 & Differentiation & 535 & 2780 & 15 & Angiogenesis & 304 & 1783 \\
\hline 6 & Stromal cells & 486 & 2628 & 16 & Regeneration & 290 & 1814 \\
\hline 7 & Myocardial infarction & 482 & 2707 & 17 & Stem cells & 283 & 1674 \\
\hline 8 & In vitro & 473 & 2476 & 18 & Cardiomyocytes & 273 & 1603 \\
\hline 9 & Therapy & 472 & 2708 & 19 & Heart failure & 273 & 1529 \\
\hline 10 & Progenitor cells & 458 & 2634 & 20 & Repair & 272 & 1683 \\
\hline
\end{tabular}

researched regulatory factors [43-46], drugs [47-49], and tracking tools [50-52], which improve efficacy of MSCs in transplantation, differentiation, and proliferation. The last three parts studied mechanisms of MSCs in antioxidant, anti-inflammatory, and anti-apoptotic. The mechanisms contain effects of inducible factor and drugs, such as high density lipoprotein (HDL) [53], telomere repeat binding factor 2 interacting protein 1 (terf2ip), Asprosin [54], Nicorandil [55], Metformin [56], and artemisinin [57].

The green cluster focused on marrow mononuclear cells, endothelial progenitor cells, acute myocardial

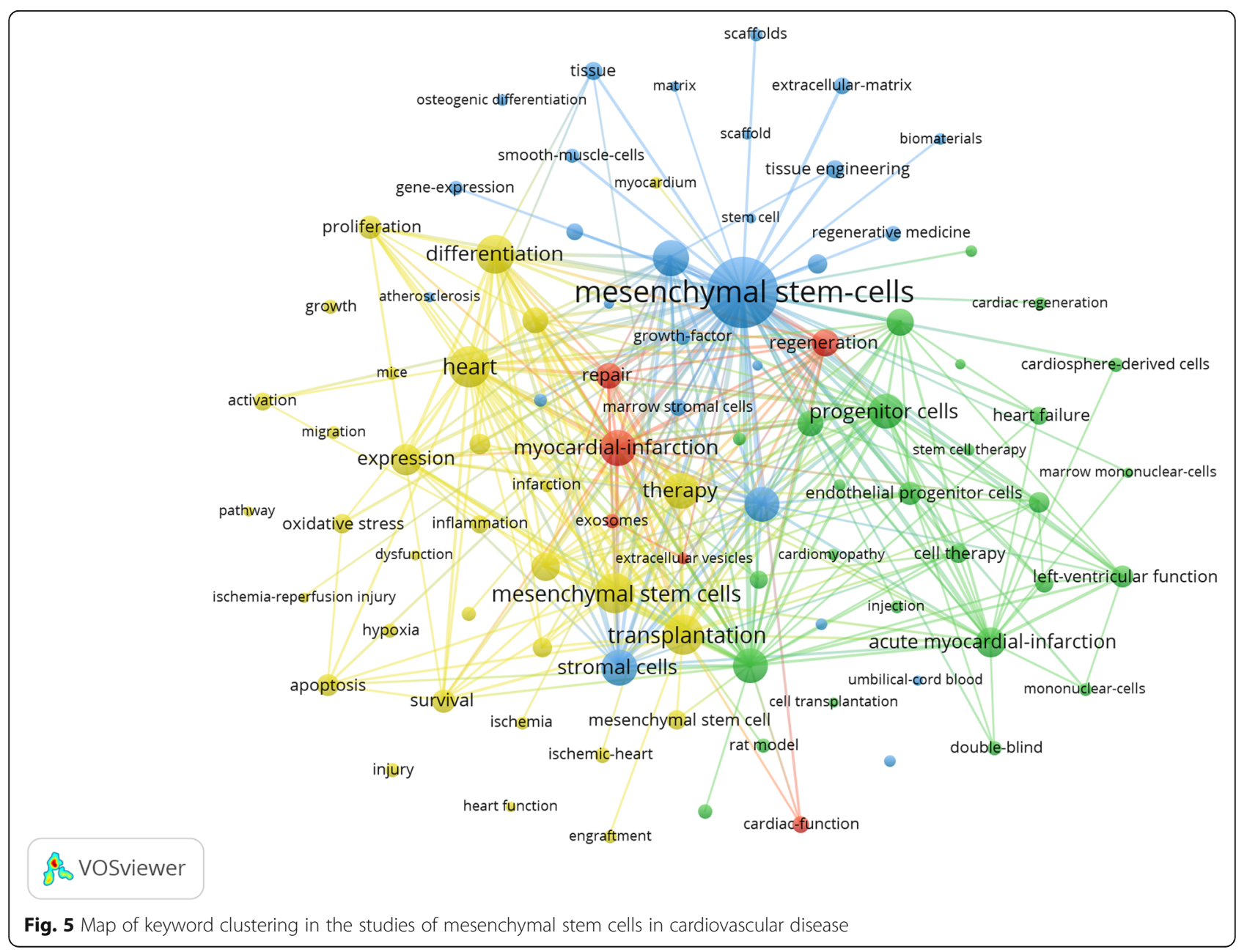


infarction, left ventricular function, and double blind. Marrow mononuclear cells researched the comparison of MSCs and BMSCs in safety of intracardiac injection $[58,59]$. Endothelial progenitor cells investigated effect of MSCs and EPCs in inducing vascular smooth muscle and promoting angiogenesis [60,61]. Acute myocardial infarction and left ventricular function discussed myocardial protective mechanism of MSCs. MiR-133 [62], PKC $\varepsilon$ [63], and glucagon-like peptide-1 [64] could improve MSCs function. The enhancement of left ventricular systolic function by MSCs mainly occurred in the anterior myocardial segment near the infarcted area of LAD [65]. Double blind evaluated the clinical efficacy of MSCs in heart failure treatment by intravenous infusion [66], intramyocardial injection [67], and endocardial transport [68].

The main research topics of red cluster were exosomes and extracellular vesicles. They could mediate mir-21-5p [69], mir-223 [70], mir-26a [71], mir-210 [72], and mir-19a [73], which enhanced MSCs to play a role in angiogenesis, myocardial cell viability, and myocardial protection.

\section{Combined evolutionary path}

In Fig. 6, the year corresponding to each of the keywords is the first year it appeared in the analyzed data set. The transformation between nodes could reveal the evolution of MSCs in the cardiovascular research hotspot. From 2010 to 2012, cardiovascular MSC research began to focus on apoptosis, left ventricular function, proliferation, bone marrow cells, and endothelial cells. In 2013-2015, endothelial progenitor cells, extracellular matrix, ischemic cardiomyopathy, and tissue received increased attention in the field. From 2016 to 2017, the field turned to research on injury and oxidative stress. Tissue engineering, exosomes, and inflammation became the new focus in 20182020.

\section{Research frontier identification}

In Table 9, the timeline is depicted as a blue line, while burst detection is shown as a red segment on the blue timeline that indicates the start year, end year, and duration of the burst. In particular, we are interested in the key words with research significance, which reflect the evolutionary trend of this field.

Endothelial progenitor cells showed the strongest burst strength, followed by ischemic cardiomyopathy, cardiovascular disease, and endothelial cells. The terms progenitor cells, marrow stromal cells, and heart function appeared for the first time recently but persisted for a shorter period of time. The burst times of the terms delivery, ischemic heart, and ischemic cardiomyopathy were consistent. Tissue is the current research frontier in this field and is currently within the burst period.

\section{Discussion}

This paper used the information visualization software CiteSpace and VOSviewer to carry out bibliometric analysis of the literature on MSCs in the cardiovascular field published from 2000 to 2020 . The analysis assessed the spatial and temporal distribution, author contribution, core literature, research hotspots, and research frontier analysis. We used keyword cooccurrence analysis to

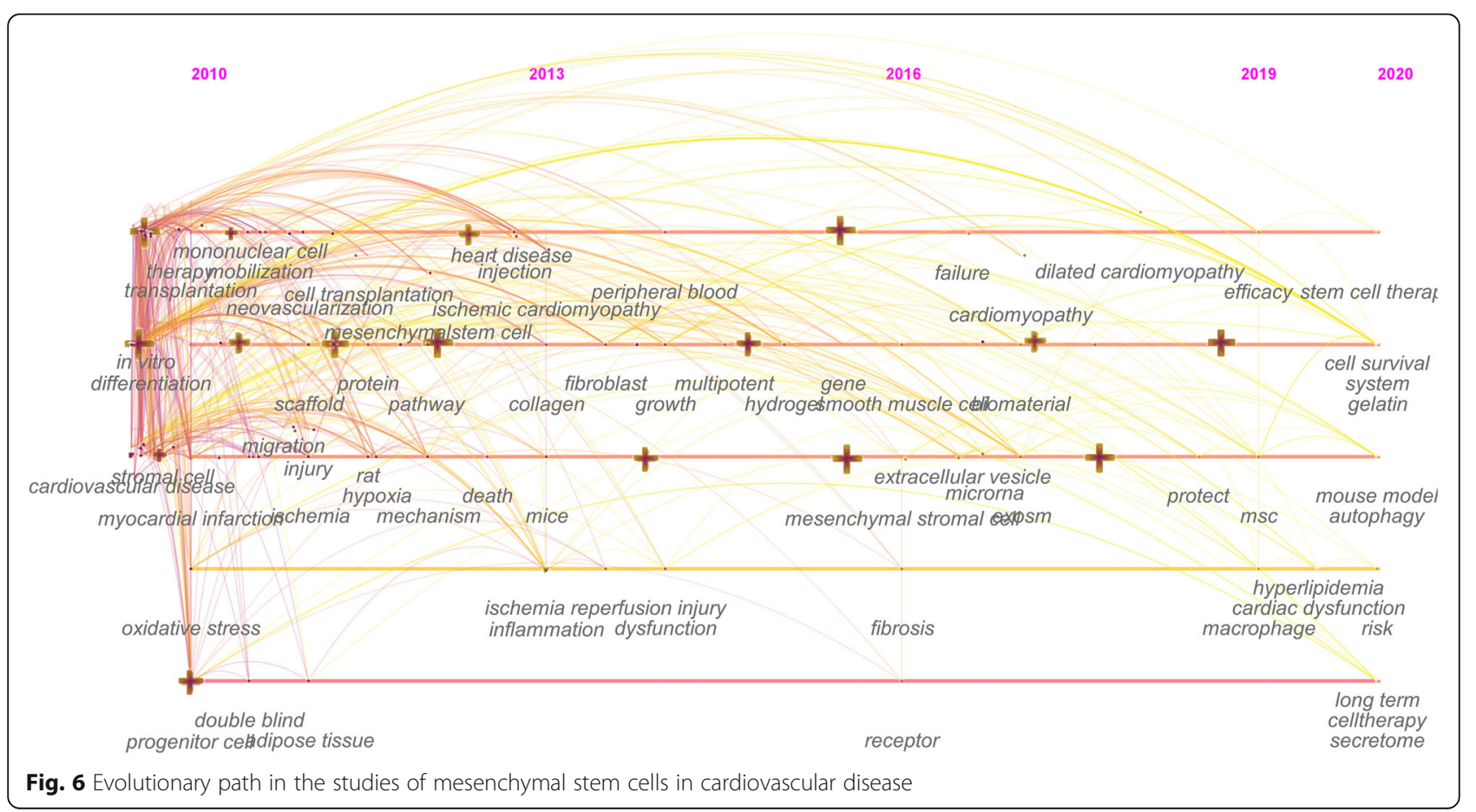


Table 9 Top 15 keywords with the strongest citation bursts

\begin{tabular}{|c|c|c|c|c|}
\hline Keywords & Strength & Begin & End & $2010-2020$ \\
\hline progenitor cell & 3.4551 & 2010 & 2011 & س \\
\hline marrow stromal cell & 12.7969 & 2010 & 2011 & 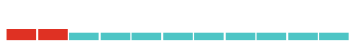 \\
\hline in vivo & 6.6078 & 2010 & 2013 & مستصس \\
\hline heart function & 10.3779 & 2010 & 2011 & 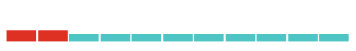 \\
\hline bone marrow cell & 13.1779 & 2010 & 2012 & (سعس \\
\hline endothelial progenitor cell & 19.2627 & 2011 & 2012 & - \\
\hline endothelial cell & 13.3878 & 2012 & 2013 & - \\
\hline cardiac function & 8.7381 & 2012 & 2013 & مسعـــ \\
\hline delivery & 3.985 & 2013 & 2016 & 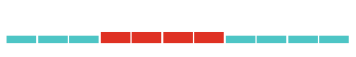 \\
\hline ischemic heart & 8.0921 & 2014 & 2015 & \\
\hline ischemic cardiomyopathy & 16.5089 & 2014 & 2017 & 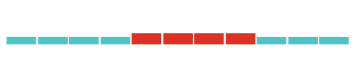 \\
\hline growth factor & 4.0519 & 2014 & 2015 & - \\
\hline cardiovascular disease & 14.8349 & 2015 & 2017 & تصس \\
\hline injury & 9.9276 & 2016 & 2017 & ت-1 \\
\hline tissue & 5.5759 & 2016 & 2020 & 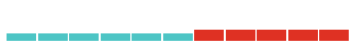 \\
\hline
\end{tabular}

identify research hotspots in each period and to determine the core evolutionary path of the theme. Then, we identified the current research frontiers of research of MSCs in the cardiovascular field. The main conclusions are as follows:

(1) The research of MSCs in the cardiovascular field showed a zigzag upward trend.

Stem cell therapy has great potential for use in future regenerative medicine treatment; however, it has some risks and limitations, such as the type of stem cells used, cell proliferation ability, differentiation status, drug delivery route, drug delivery site, and the ability for survival of transplanted cells, which will affect the therapeutic effect. The therapeutic characteristics, medical ethics, and possible teratogenicity have made the study of MSCs highly controversial [74]. For example, Hegyi et al. proposed that MSCs might form primary cardiac sarcomas and develop into tumors with multiple lineage differentiation [75]. Huang et al. reported that transplantation and differentiation of MSCs led to progressive ventricular dysfunction and other diseases [76]. In view of the risks of research and the limitations of technology, researchers are cautious in carrying out the research work.

(2) The study of cardiovascular MSCs in Europe and America started first, and Asian countries have paid increasing attention to this area of research.

European and American countries started research in this field earlier than other countries, and their research is therefore more mature. For example, Harvard University, the Mayo Clinic, and University of Cincinnati in the USA have obtained a large number of high-quality research results. Harvard University has mainly studied 3D microcapsules [77] and engineered three-layer scaffolds [78]. The Mayo Clinic has explored the effect of MSCs on left ventricular assist device (LVAD) implantation [79], left ventricular remodeling [80], and heart failure [80] through clinical trials while developing microfiber stents [81] and vascular biomaterials [82]. The paracrine effect of nuclear casein kinase on MSC and MSCderived extracellular vesicles (EVs) has been studied [83]. The University of Cincinnati explored the cardiac protection mechanism of paracrine MSCs, which involves iPS cells (MiPS) [84], the Wnt11 signaling pathway [85], CXCR4 factor expression [86], the suicide gene [87], and the clusterin Akt/GATA-4 pathway [88]. 
For the past decade, Asian countries have also paid attention to MSC research. For example, the Chinese Academy of Medical Sciences and Sun Yat-sen University in China are the leading research institutions with high achievements in the field. The Chinese Academy of Medical Sciences examined the time-distribution characteristics of MSCs in the myocardium and other organs [89]. The mechanism by which statins and Chinese medicines regulate SDF-1/CXCR4 [90], JAK-STAT [91], RhoA/ROCK [48], and AMPK/eNOS [92] in MSCs has been studied. The Chinese Academy of Medical Sciences also explored the improvement of cardiac function by MSCs regulated by matrix-derived factor 1 (SDF1a) [93] and CXC chemokine receptor 4 (CXCR4) [94]. Sun Yatsen University researched the effects of exons (Exo) [95], the TGF- $\beta$ superfamily [96], the long noncoding RNA brave heart (lncRNA-Bvht) [97], apelin [98], and granulocyte colony stimulating factor (G-CSF) [99] on the proliferation, differentiation, and vascularization of MSCs. The functions of the transcription factors islet-1 (ISL1) [100] and platelet fibrin (PRF) [101] in regulating the repair of myocardial infarction by MSCs have been explored. Although basic research on cardiovascular stem cells in China is at the forefront of efforts around the world, progress on clinical studies in China is stagnant, which may be related to the lack of efficient scientific approval systems and strict regulatory policies.

(3) Multidisciplinary intersection provides power and technical support for the development of this field.

The literature published in this field is mainly focused on cell biology, cardiovascular system cardiology, and research experimental medicine, as well as engineering, materials science, chemistry, biophysics, and other disciplines, which reflects that multidisciplinary intersection is a characteristic of research in this field. Engineering and materials disciplines, such as bioengineering [102], tissue engineering [103], genetic engineering [104, 105], and biomaterials [106], have received special attention from scholars. The development of these related disciplines will aid in breaking through the limitations of the technical conditions of research in this field.

(4) Tissue research is a hot spot and frontier area in this field.

Tissue research refers to tissue repair and tissue engineering. Heart failure caused by ischemic and nonischemic cardiomyopathy is due to the progressive and complex process of myocardial remodeling. Local compensatory changes at the genetic, molecular, cellular, and interstitial levels are accompanied by ventricular dilatation and the impairment of systolic and diastolic function. The consequence is that billions of cardiomyocytes replaced by fibrous tissue, and the cardiomyocytes and vascular cells are severely injured [107]. Although it has been confirmed that the adult heart contains a small number of active circulating cells, resident stem cells, and progenitor cells [108], its inherent ability for selfregeneration is unable to compensate for the loss in cell quality due to heart failure. At present, heart transplantation is the only treatment that can completely restore heart function for patients with advanced heart failure. However, due to the shortage of donors, this treatment is often limited. The need to cell therapy has aroused great interest in regenerative medicine.

MSCs have advantages in differentiating into cardiomyocytes [109], protection of cardiac muscle cells from apoptosis [110], promotion of vascular endothelial cell recovery [111], angiogenesis [112], and myocardial tissue repair [113], which is the hot spot of cardiovascular regeneration medicine research.

Because MSCs have low retention rate and poor survival rate, they need to be combined with various forms of bioactive tissue structure and effectively integrated into target tissue, which in order to regenerate cardiac tissue and improve cardiac function, such as polyurethane patch [114], elastic mold [115] based on type I collagen and matrix gel, fibrin patch [116], and Graphene [117]. Tissue engineering technology is the key strategy to repair myocardial tissue.

\section{Conclusion}

MSCs have important research value and broad application prospects in the field of cardiovascular. With the help of information visualization technology, we have obtained a more in-depth understanding of the study progression, evolutionary path, frontier hot spots, and future trends of the research of MSCs in cardiovascular disease over the past 10 years. Multinational cooperation and multidisciplinary intersection are the characteristics and trend of the development in the field, and tissue engineering will be the focus of future research.

\section{Abbreviations \\ ADMSCs: The adipose tissue-derived mesenchymal stem cells; AMPK: AMP- activated protein kinase; CD: Cluster of differentiation; CXCR4: The chemokine CXC motif receptor 4; DCM: Dilated cardiomyopathy; eNOS: Endothelial NO synthase; HF: Heart failure; HTMSCs: Human thymus- derived mesenchymal stem cells; HUCMSCs: Human umbilical cord mesenchymal stem cells; iPS: Induced pluripotent stem; JAK: Janus kinases; LAD: Left anterior descending artery; PKC: Protein kinase C; RhoA: Ras homolog family member A; ROCK: Rho-kinase; SDF-1: Stromal cell derived factor-1; STAT: Signal transducer and activator of transcription}

\section{Acknowledgements \\ Not applicable.}

\section{Authors' contributions}

C.C. and W.M. conceived and designed the experiments. X.Y.L. and Y.L. analyzed the data. Z.T.L and L.Q.Z. contributed reagents, materials, and 
analysis tools. C.C. and X.Y.L. wrote the manuscript. Z.T.L and Y.L contributed to the revision of the manuscript. The authors read and approved the final manuscript.

\section{Funding}

This work was supported by Hangzhou Municipal Health Commission Projects (No.20181228Y90), Zhejiang Medical Science and Technology Projects (No.2020RC104), and National Natural Science Foundation of China (81673706).

\section{Availability of data and materials}

The datasets used and/or analyzed during the current study are available from the corresponding author on reasonable request.

\section{Ethics approval and consent to participate}

Not applicable.

\section{Consent for publication}

Not applicable.

\section{Competing interests}

The authors declare that there are no conflicts of interest regarding the publication of this paper.

\section{Author details}

${ }^{1}$ Hangzhou Xiaoshan district Hospital of TCM, Jiangnan Hospital Affiliated to Zhejiang Chinese Medical University, Hangzhou 311201, Zhejiang, China. ${ }^{2}$ Zhejiang Chinese Medical University, Hangzhou 310053, Zhejiang, China. ${ }^{3}$ The first Affiliated Hospital Zhejiang Chinese Medical University, Hangzhou 311006, Zhejiang, China.

Received: 13 October 2020 Accepted: 3 November 2020

\section{Published online: 25 November 2020}

\section{References}

1. Kim N, Cho SG. Clinical applications of mesenchymal stem cells. Korean J Intern Med. 2013;28(4):387-402.

2. Mcintosh K, Zvonic S, Garrett S, et al. The immunogenicity of human adipose-derived cells: temporal changes in vitro. Stem Cells. 2006;24(5): 1246-53.

3. Yagi H, Soto-Gutierrez A, Parekkadan B, et al. Mesenchyma1 stem cells: mechanisms of immunomodulation and homing. Cell Transplant. 2010; 19(6):667-79.

4. Bonnet $P, A$ wede $B$, Rochefort GY, et al. Electrophysiological maturation of rat mesenchymal stem cells after induction of vascular smooth muscle cell differentiation in vitro. Stem Cells Dev. 2008;17(6):1131-40.

5. Karantalis V, Hare JM. Use of mesenchymal stem cells for therapy of cardiac disease. Circ Res. 2015;116(8):1413-30.

6. Rahbarghazi R, Nassiri SM, Ahmadi SH, et al. Dynamic induction of proangiogenic milieu after transplantation of marrow-derived mesenchymal stem cells in experimental myocardial infarction. Int J Cardiol. 2014;173(3): 453-66.

7. Lee J, Lee S, Youn Y, et al. A randomized, open-label, multicenter trial for the safety and efficacy of adult mesenchymal stem cells after acute myocardial infarction. J Korean Med Sci. 2014;29(1):23-31.

8. Chin SP, Poey AC, Wong CY, et al. Intramyocardial and intracoronary autologous bone marrow-derived mesenchymal stmmal cell treatment in chronic severe dilated cardiomyopathy. Cytotherapy. 2011;13(7):814-21.

9. Bartunek J, Behfar A, Dolatabadi D, et al. Cardiopoietie stem cell therapy in heart failure:the C- CURE cardiopoietic stem cell therapy in heart failure multicenter randomized trial with lineage- specified biologics. J Am Coll Cardiol. 2013;61(23):2329-38

10. Ekinci S, Agilli M, Ersen O, Ekinci GH. Letter to the editor regarding analysis of changing paradigms of management in 179 patients with spinal tuberculosis during a 12-year period and proposal of a new management algorithm. World Neurosurg. 2015;84(6):2072.

11. Zou X, Yue WL, Vu HL. Visualization and analysis of mapping knowledge domain of road safety studies. Accid Anal Prev. 2018;118:131-45.

12. Avcu G, Sahbudak Bal Z, Duyu M. Thanks to trauma: a delayed diagnosis of Pott disease. Emerg Care. 2015;31(12):e17-8.
13. Gao $Y$, Wang $Y$, Zhai $X$, et al. Publication trends of research on diabetes mellitus and T cells (1997-2016): a 20-year bibliometric study. Plos One. 2017; 12:e0184869.

14. Lin $\mathrm{X}$, Chen Z, Wang $\mathrm{H}$, Zheng $\mathrm{C}$, Jiang J. Bibliometric and visualized analysis of scientific publications on atlantoaxial spine surgery based on Web of Science and VOSviewer. World Neurosurg. 2020;137:435-442.e4.

15. Saheb T, Saheb M. Analyzing and visualizing knowledge structures of health informatics from 1974 to 2018: a bibliometric and social network analysis. Healthc Inform Res. 2019;25(2):61-72.

16. Lu K, Yu S, Sun D, Xing H, An J, et al. Scientometric analysis of SIRT6 studies. Med Sci Monit. 2018;24:8357-71.

17. Gan J, Cai Q, Galer P, Ma D, Chen X, et al. Mapping the knowledge structure and trends of epilepsy genetics over the past decade: a co-word analysis based on Medical Subject Headings Terms. Medicine (Baltimore). 2019;8(32): e16782.

18. Beshyah WS, Beshyah SA. Bibliometric analysis of the literature on Ramadan fasting and diabetes in the past three decades (1989-2018). Diabetes Res Clin Pract. 2019;151:313-22.

19. van Eck NJ, Waltman L. Software survey: VOSviewer, a computer program for bibliometric mapping. Scientometrics. 2010;84(2):523-38.

20. Chen C. Searching for intellectual turning points: progressive knowledge domain visualization. Proc Natl Acad Sci U S A. 2004;101(Suppl 1):5303-10.

21. Chen C. CiteSpace II: detecting and visualizing emerging trends and transient patterns in scientific literature. J Am Soc Inf Sci Technol. 2006;57(3): 359-77.

22. Armulik A, Genové G, Betsholtz C. Pericytes: developmental, physiological, and pathological perspectives, problems, and promises. Dev Cell. 2011;21(2): $193-215$.

23. Hare JM, Fishman JE, Gerstenblith G, DiFede Velazquez DL, Juan P, et al. Comparison of allogeneic vs autologous bone marrow-derived mesenchymal stem cells delivered by transendocardial injection in patients with ischemic cardiomyopathy: the POSEIDON randomized trial. JAMA. 2012;308(22):2369-79.

24. Stephen F Badylak, Doris Taylor, Korkut Uygun. Whole-organ tissue engineering: decellularization and recellularization of three-dimensional matrix scaffolds Annu Rev Biomed Eng 2011;13:27-53.

25. He Q. Knowledge discovery through co-word analysis. Libr Trends. 1999; 48(1):133-59.

26. lacobazzi D, Swim MM, Albertario A, Caputo M, Ghorbel MT. Thymusderived mesenchymal stem cells for tissue engineering clinical-grade cardiovascular grafts. Tissue Eng Part A. 2018;24(9-10):794-808.

27. Li Q, Guo Z-K, Chang Y-Q, et al. Gata4, Tbx5 and Baf60c induce differentiation of adipose tissue-derived mesenchymal stem cells into beating cardiomyocytes. Int J Biochem Cell Biol. 2015;66:30-6.

28. Jiang L, Wang Y, Pan F, et al. Synergistic effect of bioactive lipid and condition medium on cardiac differentiation of human mesenchymal stem cells from different tissues. Cell Biochem Funct. 2016;34(3):163-72.

29. Guan J, Wang F, Li Z, et al. The stimulation of the cardiac differentiation of mesenchymal stem cells in tissue constructs that mimic myocardium structure and biomechanics. Biomaterials. 2011;32(24):5568-80.

30. Chatzinikolaidou M, Kaliva M, Batsali A, et al. Wharton's jelly mesenchymal stem cell response on chitosan-graft-poly ( $\varepsilon$-caprolactone) copolymer for myocardium tissue engineering. Curr Pharm Des. 2014;20(12):2030-9.

31. Chen J, Zhan $Y$, Wang $Y$, et al. san/silk fibroin modified nanofibrous patches with mesenchymal stem cells prevent heart remodeling post-myocardial infarction in rats. Acta Biomater. 2018;80:154-68.

32. Usprech J, Romero DA, Amon CH, Simmons CA. Combinatorial screening of 3D biomaterial properties that promote myofibrogenesis for mesenchymal stromal cell-based heart valve tissue engineering. Acta Biomater. 2017;58: 34-43.

33. Mathapati S, Bishi DK, Venugopal JR, Cherian KM, Guhathakurta S, Ramakrishna S, Verma RS. Nanofibers coated on acellular tissue-engineered bovine pericardium supports differentiation of mesenchymal stem cells into endothelial cells for tissue engineering. Nanomedicine (Lond). 2014;9(5):623-34.

34. Cui X-j, Xie H, Wang $\mathrm{H}-\mathrm{j}$, et al. Transplantation of mesenchymal stem cells with self-assembling polypeptide scaffolds is conducive to treating myocardial infarction in rats. Tohoku J Exp Med. 2010;222(4):281-9.

35. Lin Y-L, Chen C-P, Lo C-M, Wang H-S. Stiffness-controlled three-dimensional collagen scaffolds for differentiation of human Wharton's jelly mesenchymal stem cells into cardiac progenitor cells. J Biomed Mater Res A. 2016;104(9): 2234-42. 
36. Ceccaldi C, Fullana SG, Alfarano C, et al. Alginate scaffolds for mesenchymal stem cell cardiac therapy: influence of alginate composition. Cell Transplant. 2012;21(9):1969-84.

37. Papalamprou A, Chang CW, Vapniarsky N, et al. Xenogeneic cardiac extracellular matrix scaffolds with or without seeded mesenchymal stem cells exhibit distinct in vivo immunosuppressive and regenerative properties. Acta Biomater. 2016;45:155-68.

38. Catherine Le Visage, Olivier Gournay, Najah Benguirat, et al .Françoise Norol. Mesenchymal stem cell delivery into rat infarcted myocardium using a porous polysaccharide-based scaffold: a quantitative comparison with endocardial injection. Tissue Eng Part A 2012 18(1-2):35-44.

39. Arslan YE, Galata YF, Arslan TS, et al. Trans-differentiation of human adipose derived mesenchymal stem cells into cardiomyocyte-like cells on decellularized bovine myocardial extracellular matrix-based films. J Mater Sci Mater Med. 2018:29(8):127.

40. Ciuffreda MC, Malpasso G, Chokoza C, et al. Synthetic extracellular matrix mimic hydrogel improves efficacy of mesenchymal stromal cell therapy for ischemic cardiomyopathy. Acta Biomater. 2018;70:71-83.

41. Schmuck EG, Mulligan JD, Ertel RL, et al. Cardiac fibroblast-derived $3 \mathrm{D}$ extracellular matrix seeded with mesenchymal stem cells as a novel device to transfer cells to the ischemic myocardium. Cardiovasc Eng Technol. 2014;5(1):119-31.

42. Chang CW, Petrie T, Clark A, Lin X, et al. Mesenchymal stem cell seeding of porcine small intestinal submucosal extracellular matrix for cardiovascular applications. Plos One. 2016;11(4):e0153412.

43. Ding $Y$, Liang $X$, Zhang $Y$, et al. Rap1 deficiency-provoked paracrine dysfunction impairs immunosuppressive potency of mesenchymal stem cells in allograft rejection of heart transplantation. Cell Death Dis. 2018; 9(3):386.

44. Liu X-B, Wang J-A, Ji X-Y, et al. Preconditioning of bone marrow mesenchymal stem cells by prolyl hydroxylase inhibition enhances cell survival and angiogenesis in vitro and after transplantation into the ischemic heart of rats. Stem Cell Res Ther. 2014;5(5):111.

45. Preda MB, Rønningen T, Burlacu A, et al. Remote transplantation of mesenchymal stem cells protects the heart against ischemia-reperfusion injury. Stem Cells. 2014;32(8):2123-34.

46. Liu X, Chen H, Zhu W, et al. Transplantation of SIRT1-engineered aged mesenchymal stem cells improves cardiac function in a rat myocardial infarction model. J Heart Lung Transplant. 2014;33(10):1083-92.

47. Zhang G-W, Tian-Xiang G, Sun X-J, et al. Edaravone promotes activation of resident cardiac stem cells by transplanted mesenchymal stem cells in a rat myocardial infarction model. J Thorac Cardiovasc Surg. 2016; 152(2):570-82.

48. Zhang $\mathrm{Q}$, Wang $\mathrm{H}$, Yue-JinYang, et al. Atorvastatin treatment improves the effects of mesenchymal stem cell transplantation on acute myocardial infarction: the role of the RhoA/ROCK/ERK pathway. Int J Cardiol. 2014; 176(3):670-9.

49. Han X-J, Li H, Liu C-B, et al. Danshen Formulation improved the effect of mesenchymal stem cells transplantation for the treatment of myocardial infarction probably via enhancing the engraftment. Life Sci. 2019;233:116740.

50. Jian Cao, Yi-ning Wang, Xin-lin Shi, et al. In vivo and in vitro imaging tracing of dual-labeled bone mesenchymal stem cells transplanted into myocardium of F344 rats. Acta Academiae Medicinae Sinicae. 2012;34(5): 474-9.

51. Hu S, Cao W, Lan X, et al. Comparison of rNIS and hNIS as reporter genes for noninvasive imaging of bone mesenchymal stem cells transplanted into infarcted rat myocardium. Mol I. 2011;10(4):227-37.

52. Ma N, Cheng H, Lu M, et al. Magnetic resonance imaging with superparamagnetic iron oxide fails to track the long-term fate of mesenchymal stem cells transplanted into heart. Sci Rep. 2015;5:9058.

53. Xu J, Qian J, Xie X, et al. High density lipoprotein protects mesenchymal stem cells from oxidative stress-induced apoptosis via activation of the PI3K/Akt pathway and suppression of reactive oxygen species. Int J Mol Sci. 2012;13(12):17104-20.

54. Zhang Z, Tan Y, Zhu L, et al. Asprosin improves the survival of mesenchymal stromal cells in myocardial infarction by inhibiting apoptosis via the activated ERK1/2-SOD2 pathway. Life Sci. 2019;231: 116554

55. Mohamed SS, Ahmed LA, Attia WA, Khattab MM. Nicorandil enhances the efficacy of mesenchymal stem cell therapy in isoproterenol-induced heart failure in rats. Biochem Pharmacol. 2015;98(3):403-11.
56. He X, Yao M-W, Zhu M, et al. Metformin induces apoptosis in mesenchymal stromal cells and dampens their therapeutic efficacy in infarcted myocardium. Stem Cell Res Ther. 2018;9(1):306.

57. Fang J, Zhao X, Li S, et al. Protective mechanism of artemisinin on rat bone marrow-derived mesenchymal stem cells against apoptosis induced by hydrogen peroxide via activation of c-Raf-Erk1/2-p90 rsk-CREB pathway. Stem Cell Res Ther. 2019;10(1):312.

58. Dolores Carmona M, Cañadillas S, Romero M, et al. Intramyocardial bone marrow mononuclear cells versus bone marrow-derived and adipose mesenchymal cells in a rat model of dilated cardiomyopathy. Cytotherapy. 2017;19(8):947-61.

59. van der Spoel TIG, Gathier WA, Koudstaal S, et al. Autologous mesenchymal stem cells show more benefit on systolic function compared to bone marrow mononuclear cells in a porcine model of chronic myocardial infarction. J Cardiovasc Transl Res. 2015;8(7):393-403.

60. Kawamura M, Paulsen MJ, Goldstone AB, et al. Tissue-engineered smooth muscle cell and endothelial progenitor cell bi-level cell sheets prevent progression of cardiac dysfunction, microvascular dysfunction, and interstitial fibrosis in a rodent model of type 1 diabetes-induced cardiomyopathy. Cardiovasc Diabetol. 2017;16(1):142.

61. Vrijsen KR, Maring JA, Chamuleau SAJ, et al. Exosomes from cardiomyocyte progenitor cells and mesenchymal stem cells stimulate angiogenesis via EMMPRIN. Adv Healthc Mater Actions. 2016;5(19):2555-65.

62. Chen $Y$, Zhao $Y$, Chen W, et al. MicroRNA-133 overexpression promotes the therapeutic efficacy of mesenchymal stem cells on acute myocardial infarction. Stem Cell Res Ther. 2017;8(1):268.

63. He H, Zhao Z-H, Han F-S, et al. Overexpression of protein kinase $\mathrm{C} \varepsilon$ improves retention and survival of transplanted mesenchymal stem cells in rat acute myocardial infarction. Cell Death Dis. 2016;7(1):e2056.

64. de Jong R, van Hout GPJ, Houtgraaf JH, et al. Intracoronary infusion of encapsulated glucagon-like peptide-1-eluting mesenchymal stem cells preserves left ventricular function in a porcine model of acute myocardial infarction. Circ Cardiovasc Interv. 2014;7(5):673-83.

65. Kim SH, Cho JH, Lee $\mathrm{YH}$, et al. Improvement in left ventricular function with intracoronary mesenchymal stem cell therapy in a patient with anterior wall ST-segment elevation myocardial infarction. Cardiovasc Drugs Ther. 2018; 32(4):329-38.

66. Bartolucci J, Verdugo FJ, González PL, et al. Safety and efficacy of the intravenous infusion of umbilical cord mesenchymal stem cells in patients with heart failure: a phase 1/2 randomized controlled trial (RIMECARD Trial [Randomized Clinical Trial of Intravenous Infusion Umbilical Cord Mesenchymal Stem Cells on Cardiopathy]). Circ Res. 2017;121(10):1192-204.

67. Mathiasen AB, Qayyum AA, Jørgensen E, et al. Bone marrow-derived mesenchymal stromal cell treatment in patients with severe ischaemic heart failure: a randomized placebo-controlled trial (MSC-HF trial). Eur Heart J. 2015;36(27):1744-53.

68. Trachtenberg B, Velazquez DL, Williams AR, et al. Rationale and design of the Transendocardial Injection of Autologous Human Cells (bone marrow or mesenchymal) in Chronic Ischemic Left Ventricular Dysfunction and Heart Failure Secondary to Myocardial Infarction (TAC-HFT) trial: a randomized, double-blind, placebo-controlled study of safety and efficacy. Am Heart J Actions. 2011;161(3):487-93.

69. Mayourian J, Ceholski DK, Gorski PA, et al. Exosomal microRNA-21-5p mediates mesenchymal stem cell paracrine effects on human cardiac tissue contractility. Circ Res. 2018;122(7):933-44.

70. Wang $X$, Haitao G, Qin D, et al. Exosomal miR-223 contributes to mesenchymal stem cell-elicited cardioprotection in polymicrobial sepsis. Sci Rep. 2015;5:13721.

71. Zhao J, Li X, Hu J, et al. Mesenchymal stromal cell-derived exosomes attenuate myocardial ischaemia-reperfusion injury through miR-182regulated macrophage polarization. Cardiovasc Res. 2019;115(7):1205-16.

72. Mao Q, Liang X-L, Zhang C-L, et al. LncRNA KLF3-AS1 in human mesenchymal stem cell-derived exosomes ameliorates pyroptosis of cardiomyocytes and myocardial infarction through miR-138-5p/Sirt1 axis. Stem Cell Res Ther. 2019;10(1):393.

73. Ma J, Zhao Y, Sun L, et al. Exosomes derived from Akt-modified human umbilical cord mesenchymal stem cells improve cardiac regeneration and promote angiogenesis via activating platelet-derived growth factor D. Stem Cells Transl Med. 2017;6(1):51-9.

74. Wei X, Yang X, Han ZP, Qu FF, Shao L, Shi YF. Mesenchymal stem cells: a new trend for cell therapy. Acta Pharmacol Sin. 2013;34(6):747-54. 
75. Hegyi L, Thway K, Fisher C, Sheppard MN. Primary cardiac sarcomas may develop from resident or bone marrow-derived mesenchymal stem cells: use of immunohistochemistry including CD44 and octamer binding protein 3/4. Histopathology. 2012;61(5):966-73.

76. Huang XP, Sun Z, Miyagi Y, McDonald Kinkaid H, Zhang L, Weisel RD, Li RK. Differentiation of allogeneic mesenchymal stem cells induces immunogenicity and limits their long-term benefits for myocardial repair. Circulation. 2010;122(23):2419-29.

77. Li Y, Liu W, Liu F, Yang Z, Zuo S. Primed 3D injectable microniches enabling low-dosage cell therapy for critical limb ischemia. Proc Natl Acad Sci U S A. 2014;111(37):13511-6.

78. Masoumi N, Annabi N, Assmann A, Larson BL, Hjortnaes J. Tri-layered elastomeric scaffolds for engineering heart valve leaflets. Biomaterials. 2014; 35(27):7774-85.

79. Ascheim DD, Gelijns AC, Goldstein D, Moye LA, Smedira N, et al. Mesenchymal precursor cells as adjunctive therapy in recipients of contemporary left ventricular assist devices. Circulation. 2014;129(22):2287-96.

80. John R Teerlink, Marco Metra, Gerasimos S Filippatos, Beth A Davison, Jozef Bartunek, et al. Benefit of cardiopoietic mesenchymal stem cell therapy on left ventricular remodelling: results from the Congestive Heart Failure Cardiopoietic Regenerative Therapy (CHART-1) study.Eur J Heart Fail 2017; 19(11):1520-1529.

81. Jana S, Bhagia A, Lerman A. Optimization of polycaprolactone fibrous scaffold for heart valve tissue engineering. Biomed Mater. 2019;14(6):065014

82. Alfonso-Garcia A, Shklover J, Sherlock BE, Panitch A, Griffiths LG, Marcu L. Fiber-based fluorescence lifetime imaging of recellularization processes on vascular tissue constructs. J Biophotonics. 2018;11(9):e201700391.

83. Zhang Y, Chiu S, Liang X, Chai Y-H, Qin Y, Wang J, Li X. Absence of NUCKS augments paracrine effects of mesenchymal stem cells-mediated cardiac protection. Exp Cell Res. 2017;356(1):74-84.

84. Buccini S, Haider KH, Ahmed RPH, Jiang S, Ashraf M. Cardiac progenitors derived from reprogrammed mesenchymal stem cells contribute to angiomyogenic repair of the infarcted heart. Basic Res Cardiol. 2012;107(6):301.

85. He Z, Li H, Zuo S, Pasha Z, Wang Y, Yang Y, Jiang W, Ashraf M, Meifeng X. Transduction of Wnt11 promotes mesenchymal stem cell transdifferentiation into cardiac phenotypes. Stem Cells Dev. 2011;20(10): 1771-8.

86. Kang K, Ma R, Cai W, Huang W, Paul C, et al. Exosomes secreted from CXCR4 overexpressing mesenchymal stem cells promote cardioprotection via Akt signaling pathway following myocardial infarction. Stem Cells Int 2015;2015:659890.

87. Liang J, Huang W, Yu X, Ashraf A, Wary KK, Xu M, Millard RW, Ashraf M, Wang $Y$. Suicide gene reveals the myocardial neovascularization role of mesenchymal stem cells over expressing CXCR4 (MSC (CXCR4)). Plos One. 2012;7(9):e46158.

88. Yu B, Yang Y, Liu H, Gong M, Millard RW, Wang Y-G, Ashraf M, Xu M Clusterin/Akt up-regulation is critical for GATA-4 mediated cytoprotection of mesenchymal stem cells against ischemia injury. Plos One. 2016;11(3): e0151542.

89. Ma N, Cheng H, Lu M, Liu Q, Chen X, Yin G, Zhu H, Zhang L, Meng X, Tang $Y$, Zhao S. Magnetic resonance imaging with superparamagnetic iron oxide fails to track the long-term fate of mesenchymal stem cell stransplanted into heart. Sci Rep. 2015;5:9058

90. Tian X-Q, Yang Y-J, Li Q, Xu J, Huang P-S, Xiong Y-Y, Li X-D, Jin C, Qi K, Jiang L-P, Chen G-H, Qian L, Liu J, Geng Y-J. Combined therapy with atorvastatin and atorvastatin-pretreatedmesenchymalstemcellsenhances cardiac performance after acute myocardial infarction by activating SDF-1/CXCR4 axis. Am J Transl Res. 2019;11(7):4214-31.

91. Xu H, Yang Y-J, Qian H-Y, Tang Y-D, Wang H, Zhang Q. Rosuvastatin treatment activates JAK-STAT pathway and increases efficacy of allogeneic mesenchymal stem cell transplantation in infarcted hearts. Circ J. 2011;75(6): 1476-85.

92. Li N, Yang Y-J, Cui H-H, Zhang Q, Jin C, Qian H-Y, Dong Q-T, Zhang H. Tongxinluo decreases apoptosis ofmesenchymalstemcellsconcentrationdependently under hypoxia and serum deprivation conditions through the AMPKJeNOS pathway. J Cardiovasc Pharmacol. 2014;63(3):265-73.

93. Gong X-H, Liu H, Wang S-J, Liang S-W, Wang G-G. Exosomes derived from SDF1-overexpressing mesenchymal stem cells inhibit ischemic myocardial cell apoptosis and promote cardiac endothelial microvascular regeneration in mice with myocardial infarction. J Cell Physiol. 2019;234(8):13878-93.
94. Li N, Yang Y-J, Qian H-Y, Li Q, Zhang Q, Li X-D, Dong Q-T, Xu H, LeiSong, HaoZhang. Intravenous administration of atorvastatinpretreated mesenchymal stem cell simproves cardiac performance after acute myocardial infarction: role of CXCR4. Am J Transl Res. 2015;7(6): 1058-70.

95. Huang P, Wang L, Li Q, Xu J, Xu J, Xiong Y, Chen G, Qian H, Jin C, Yu Y, Liu J, Qian L, Yang Y. Combinatorial treatment of acute myocardial infarction using stem cells and their derived exosomes resulted in improved heart performance. Stem Cell Res Ther. 2019;10(1):300.

96. Ai W-J, Li J, Lin S-M, Li W, Liu C-Z, LV W-M. R-Smad signaling-mediated VEGF expression coordinately regulates endothelial cell differentiation of ratmesenchymalstemcells. Stem Cells Dev. 2015;24(11):1320-31.

97. Hou J, Long H, Zhou C, Zheng S, Wu H, Guo T, Wu Q, Zhong T, Wang T. Long noncoding RNA Braveheart promotes cardiogenic differentiation of mesenchymal stem cells in vitro. Stem Cell Res Ther. 2017;8(1):4.

98. Hou J, Zhong T, Guo T, Miao C, Zhou C, Long H, Wu H, Zheng S, Wang L, Wang T. Apelin promotes mesenchymal stem cells survival and vascularization under hypoxic-ischemic condition in vitro involving the upregulation of vascular endothelial growth factor. Exp Mol Pathol. 2017; 102(2):203-9.

99. Zhao $Y$, Liu $Y X$, Xie SL, Deng BQ, Wang JF, Nie RQ. Increased expression of granulocyte colony-stimulating factor mediates mesenchymal stem cells recruitment after vascular injury. Chin Med J. 2011;124(24):4286-92.

100. Xiang Q, Liao Y, Chao H, Huang W, Liu J, Chen H, Hong D, Zou Z, Xiang AP, Li W. ISL1 overexpression enhances the survival of transplanted humanmesenchymalstemcellsin a murine myocardial infarction model. Stem Cell Res Ther. 2018;9(1):51.

101. Chen Y-L, Sun C-K, Tsai T-H, Chang L-T, Leu S, Zhen Y-Y, Sheu J-J, Chua S, Yeh K$\mathrm{H}$, Lu H-I, Chang H-W, Lee F-Y, Yip H-K. Adiposederivedmesenchymalstemcellsembedded in platelet-rich fibrin scaffolds promote angiogenesis, preserve heart function, and reduce left ventricular remodeling in rat acute myocardial infarction. Am J Transl Res. 2015;7(5):781-803.

102. Wang K, Lin R-Z, Melero-Martin JM. Bioengineering human vascular networks: trends and directions in endothelial and perivascular cell sources. Cell Mol Life Sci. 2019;76(3):421-39.

103. Emmert MY, Wolint P, Wickboldt N, Gemayel G, Weber B, Brokopp CE, Boni A, Falk V, Bosman A, Jaconi ME, Hoerstrup SP. Human stem cell-based threedimensional microtissues for advanced cardiac cell therapies. Biomaterials. 2013;34:6339-54.

104. Li J, Yoong SL, Goh WJ, et al. In vitro controlled release of cisplatin from gold-carbon nanobottles via cleavable linkages. J Int J Nanomed. 2015;10: 7425-41.

105. Shen Y, Qiao H, Fan Q, Zhang S, Tang T. Potentiated osteoinductivity via cotransfection with BMP-2 and VEGF genes in microencapsulated C2C12 cells. Biomed Res Int. 2015;2015:10.

106. Qazi TH, Mooney DJ, Duda GN, et al. Biomaterials that promote cell-cell interactions enhance the paracrine function of MSCs. Biomaterials. 2017;140:103-14.

107. Psaltis PJ, Schwarz N, Toledo-Flores D, et al. Cellular therapy for heart failure. Curr Cardiol Rev. 2016;12(3):195-215.

108. Leri A, Rota M, Hosoda T, et al. Cardiac stem cell niches. Stem Cell Res. (Amst.). 2014;13(3 Pt B):631-46.

109. Liang L, Xia Y. Study of adipose tissue-derived mesenchymal stem cells transplantation for rats with dilated cardiomyopathy. Ann Thorac Cardiovasc Surg. 2014;20(5):398-406

110. Yu B, Gong M, Wang $Y$, et al. Cardiomyocyte protection by GATA 4 gene engineered mesenchymal stem cells is partially mediated by translocation of miR-221 in microvesicles. Plos One. 2013:8(8):e73304.

111. BeiShi $X L$, RanzunZhao, et al. Transplantation of mesenchymal stem cells carrying the human receptor activity-modifying protein 1 gene improves cardiac function and inhibits neointimal proliferation in the carotid angioplasty and myocardial infarction rabbit model. Exp Biol Med (Maywood). 2014;239(3):356-65.

112. Bian S, Zhang L, Duan $L$, et al. Extracellular vesicles derived from human bone marrow mesenchymal stem cells promote angiogenesis in a rat myocardial infarction model. J Mol Med (Berl). 2014;92(4):387-97.

113. Zhao $Y$, Li T, Wei $X$, et al. Mesenchymal stem cell transplantation improves regional cardiac remodeling following ovine infarction. Stem Cells Transl Med. 2012:1 (9):685-95.

114. Florian E M Herrmann, Anja Lehner, Trixi Hollweck, et al. In vitro biological and mechanical evaluation of various scaffold materials for myocardial tissue engineering. J Biomed Mater Res A 2014;102(4):958-66. 
115. Gregory W Serrao, Irene C Turnbull, Damian Ancukiewicz, et al. Myocytedepleted engineered cardiac tissues support therapeutic potential of mesenchymal stem cells. Tissue Eng Part A 2012;18(13-14):1322-33.

116. Roura S, Soler-Botija C, Bagó JR, Llucià-Valldeperas A, et al. Postinfarction functional recovery driven by a three-dimensional engineered fibrin patch composed of human umbilical cord blood-derived mesenchymal stem cells. Stem Cells Transl Med. 2015;4(8):956-66.

117. Park J, Park S, Ryu S, et al. Graphene-regulated cardiomyogenic differentiation process of mesenchymal stem cells by enhancing the expression of extracellular matrix proteins and cell signaling molecules. Adv Healthc Mater. 2014;3(2):176-81.

\section{Publisher's Note}

Springer Nature remains neutral with regard to jurisdictional claims in published maps and institutional affiliations.

Ready to submit your research? Choose BMC and benefit from:

- fast, convenient online submission

- thorough peer review by experienced researchers in your field

- rapid publication on acceptance

- support for research data, including large and complex data types

- gold Open Access which fosters wider collaboration and increased citations

- maximum visibility for your research: over $100 \mathrm{M}$ website views per year

At BMC, research is always in progress.

Learn more biomedcentral.com/submissions 